\title{
Voices in the Open: Wordsworth, Eliot, and Stevens
}

\author{
Thomas R. Whitaker
}

\section{I}

“. . . to the open fields," says The Prelude, "I told / A prophecy . . . ." But we hear Wordsworth today in fields that seem more disturbingly open than any he could name. Perhaps that is why his most haunted and self-haunted passages have gained a special resonance. When he reascends the bare common, finds himself halted or lost, or contemplates the image of a mind

\section{that broods}

Over the dark abyss, intent to hear

Its voices issuing forth to silent light

we respond to his meaning. And he converses with more recent poets who seem antithetical to him and to each other. I want to listen to a small part of that conversation.

T. S. Eliot thought a poet's most individual passages may be those in which "the dead poets, his ancestors, assert their immortality most vigorously"but Eliot isn't noted for standing in that filial relation to Wordsworth. ${ }^{1}$ Wallace Stevens preferred to think that "the past is my own and not something marked Coleridge, Wordsworth, etc.,"-and he could also say: "Eliot and I are dead opposites." 2 Nevertheless these three poets belong to a single company. Each has been accused of the egotistical sublime. Each is most social when most solitary. Wooers of the pensive muse, they are perplexed by an epistemological uncertainty that their ancestor Milton could still subjugate. But their hesitations and ambiguities also render a faith that speech must disclose existence, that poetry must name. Each therefore knows the troubled way of the reflexive and self-transcending voice that moves in the open toward new words, new thresholds of meaning. And each finds that the long poem, the uneasy heir of the epic and georgic traditions, must now name the sustained attempt of that voice to name its calling.

Their quarrels are those of close kin. The Prelude is addressed to a friend who could say that man's divinely established end is the growth of his "reflex consciousness."3 But Four Quartets and Notes Toward a Supreme Fiction are spoken by poets who have heard "Le Serpent" declare, "Je m'écoute, et dans mes circuits, / Ma méditation murmure . . . ." From Coleridge to Valéry, as poetry intends the illusion of reflexive spontaneity, a seeming virtue becomes a 
questionable burden. Within that development Wordsworth, Eliot, and Stevens render the movement of the solitary voice toward three quite different but perhaps complementary horizons.

The most intense voices in Wordworth's poetry move toward an apparently external horizon that resists complete formulation but is often called "Nature." There they meet speaking presences that elude common sense. "Shall I call thee Bird, / Or but a wandering Voice?" That is a playful but real question. "A homeless sound of joy was in the sky." That is an exact predication.

So sweetly 'mid the gloom the invisible bird

Sang to herself, that there I could have made

My dwelling-place....

Meeting cuckoo, lark, or wren, the solitary voice seems to recognize its homeless home.

A later reason often tries to objectify that mystery by positing one life in all things, or an external entity fitted to the individual mind, or a possibly transcendental imagination. But abstract discourse about other horizons than $\mathrm{Na}-$ ture isn't central to Wordsworth's most distinctive poetry. We sometimes say that his "things forever speaking" are metaphors-that he really means an intuition of organicism or vital reciprocity. But such terms are also metaphors, and they eliminate the category of speech only by reducing what this and all poetry must face. We share a pre-reflective and inherently social power of symbolizing. That power constitutes our world by naming an unknown reality that it meets as a call to be answered. The most intense voices in Wordsworth's poetry hear that call on the horizon of Nature.

As they listen, space contains no simple locations, time is not merely linear, subjects participate each other, and solitude is community. The cuckoo's two-fold shout is distant and near, unchanged and new, a natural babble and a tale of visionary hours that enables the listener to beget his past. The earth again appears "unsubstantial," a "fit home" for that "invisible thing, / A voice, a mystery." But if a human presence is met, such paradoxes usually darken. The Cumberland beggar is almost annihilated and almost immortal. Everywhere homeless and at home, he wanders in a "vast solitude" and in "the eye of Nature," speaking silently to all who meet him. Often the voice in the poem meets a community of presences. On summer evenings the speaker in "There Was a Boy" has "stood / Mute," contemplating a grave in a churchyard that "hangs / Upon a slope above the village school." That grave recalls a boy who conversed with owls, "hung / Listening" in the deep silence, and received far into his heart the voice of mountain-torrents or in his mind a "scene" within which the "bosom of the steady lake" received the "uncertain heaven." In this manifold landscape of suspended action and eloquent falling, existence speaks to the growing boy and the dying man. In "The Ruined Cottage" another Youth, acquainted with "things that hold / An inarticulate language," feels the "mystery, the life which cannot 
die." But because that life speaks most clearly through death, the story of Margaret must end with the Wanderer's naming an image of tranquility-

Those weeds, and the high spear-grass on that wall, By mist and silent rain-drops silvered o'er ....

Other poems move more swiftly toward a stillness in which Nature seems human speech, the human seems both dead and immortal, and total solitude seems intimate communion. The strange language of "She Dwelt Among Untrodden Ways" is haunted by that condition. "A Slumber Did My Spirit Seal" names it with bare and complex finality. Poised between explicit negations and implicit affirmations, describing nothing but the silent horizon, the voice of anonymous epitaph answers its absent muse.

And yet, despite praise of "mute dialogues" and complaints of the "sad incompetence of human speech," silent communion becomes actual in each poem only through a disclosing utterance. The Wanderer says that the "senseless rocks" invoked by the poets

$$
\text { speak }
$$

In these their invocations, with a voice

Obedient to the strong creative power

Of human passion.

As part of "the great Nature that exists in works / Of mighty Poets," Wordsworth's own apparent horizon is irreducibly "Embodied in the mystery of words."

There darkness makes abode, and all the host

Of shadowy things do work their changes there,

As in a mansion like their proper home;

Even forms and substances are circumfused

By that transparent veil with light divine;

And through the turnings intricate of Verse,

Present themselves as objects recognis'd,

In flashes, and with a glory scarce their own.

If that recognition in The Prelude were itself more than an uncertain flashing, the horizon of Nature might be transcended. Because that doesn't finally occur, the doubleness inherent in all poetry takes a distinctively Wordsworthian form. A voice in the poem, moving in the field of Nature, usually speaks of a previous experience mediated by the senses. But the voice of the poem, moving in the field of conversation, always means a present experience mediated by poetry. And the poem shares the modern intention that those two voices should correspond or even converge.

Five years have passed; five summers, with the length

Of five long winters! and again I hear

These waters, rolling from their mountain-springs

With a soft inland murmur. 
As its full title suggests, "Lines Composed a Few Miles Above Tintern Abbey ..." allows its voices to correspond in a present like that of personal utterance. On July 13, 1798, the voice in the poem-an autobiographical double discovered through the act of composition-answers the speech of natural forms as he moves through improvisatory and incremental repetition in an attempt to disclose the meaning of his life. On the same apparent date-even though the poem was composed during several days, and even though poetry always speaks in the present-the voice of the poem answers Milton or Thomson or Young, Bowles or Southey or Coleridge, as it moves through intricate turnings to disclose its double's attempt. For the voice in the poem, the lengthening sequence punctuated by "summers ... winters ... . waters . . . murmur" is a spontaneously cumulative flow that answers the rolling Wye and the spirit that "rolls through all things." But for the voice of the poem the echoing chiasm means the cognition of that answer.

This is a doubleness quite different from that of the poem's great antecedent.

Yet once more, $\mathrm{O}$ ye laurels, and once more

Ye myrtles brown, with ivy never sere,

I come to pluck your berries harsh and crude,

And with forced fingers rude

Shatter your leaves before the mellowing year.

The voice in "Lycidas" speaks with images that are traditional bearers of meaning, while the voice of the poem freshly constitutes that pastoral convention. Uncouth swain and knowledgeable poet can subtly correspond without losing their clear identities-and their song almost manages to include its own narrative frame. The trompe-l'oreille of "Tintern Abbey," more immediately reflexive, makes any attempt to distinguish between the two voices seem an act of critical violence.

The day is come when I again repose

Here, under this dark sycamore, and view

These plots of cottage-ground, these orchard-tufts,

Which at this season, with their unripe fruits,

Are clad in one green hue, and lose themselves

'Mid groves and copses.

The voice in the poem meets the repetition, darkness, unripeness, and self-loss on the horizon of Nature. But the voice of the poem-which seems the same voice at the same moment-discovers those meanings through participating in the eighteenth-century conversation with Milton. As the poem proceeds, the double's insistently "cheerful faith" surmounts a sad perplexity and a possibly vain belief and is sustained by his having felt a disturbing presence or a "sense sublime / Of something...." But those dim recognitions and gleams of half-extinguished thought are among the assured precisions of the poetic voice, whose implicit joy is in the naming of such efforts to name.

Of course, Wordsworth's autobiographical double is himself more re- 
flexive than Milton's swain: "again I hear"; "Once again / Do I behold"; "How oft, in spirit, have I turned to thee"; "with what healing thoughts / . . wilt thou remember me, / And these my exhortations!" He responds to the voice and eyes of a dear Friend because they speak of his own past, and he would like to prolong his own present in her. Ominously solitary and haunted by transience, he tries to speak his own epitaph. But the implicitly social poetic voice shares that condition with a difference. In naming the anxious faith of its double, it seeks no individual life in the future. It is enough that life becomes actual now, and again now, in a quasi-repeatable and ever-deepening present. Again we hear; once again do we behold. We: for the actual poetic voice, whether discovered through composition or through reading or listening, is always our own conversationally extended and modulated voice. In its shared solitude-as it holds what The Prelude calls "fit converse with the spiritual world / And with the generations of mankind / Spread over time, past, present, and to come"-even the egotistical sublime of our double becomes an illuminated dark passage.

In contrast to "Tintern Abbey," "Resolution and Independence" seems to allow its voices to correspond in the present not of personal utterance but of poetry itself. A more distanced double, the romantic poet as lone Traveller, begins speaking in an evidently repeatable present. After referring to last night's refreshing storm he meets a Nature where

Over his own sweet voice the Stock-dove broods;

The Jay makes answer as the Magpie chatters;

And all the air is filled with pleasant noise of waters

-and where the running hare

Raises a mist; that, glittering in the sun,

Runs with her all the way, wherever she doth run.

After two stanzas he places this present in the past and doubles his own account, telling of a melancholy storm and a half-hallucinatory meeting with an answering presence: an old leech-gatherer, a stream scarce heard, a messenger from a far region.

But the poetic voice, running with its double all the way in a quasirepeatable present, doesn't need such a meeting on the horizon of Nature. Even before the Traveller tells of despairing over the fate of one who perished in his pride, the poetic voice has begun a strengthening stylistic conversation with Chatterton and his enduring ancestry. The refreshing storm assimilates the hailstorm in "The Excelente Balade of Charitie," the "hope unwilling to be fed" speaks the melancholy of Chaucer's Troilus and the falsity of the Cuckoo's attack on the Nightingale, and the leech-gatherer himself emerges from the field of Spenserian language. For the poetic voice, engaged in what The Prelude will call "converse strong and sanative" with the "One great society," to name the Traveller's crisis is to resolve it. But both voices move in a reflexive present where each mood receives its answer and the air is filled with refreshing words. 
"Tintern Abbey" and "Resolution and Independence" imply complementary ways toward the moment when the voices in and of the poem might actually converge-a moment precluded in Wordsworth's poetry by the commitment of the voice in the poem to the horizon of Nature. As the poetic voice approaches the spontaneous present of its double, the poem tends to become a fragmentary and endless personal epic. Implicit in "Tintern Abbey" is one dimension of The Prelude. But as the double approaches the quasi-repeatable present of the poetic voice, the poem tends to become a self-repeating lyric to the muse. Implicit in "Resolution and Independence" is another dimension of The Prelude and also "The Solitary Reaper."

Behold her, single in the field.

Yon solitary Highland Lass!

Reaping and singing by herself;

Stop here, or gently pass!

Who speaks to whom? In what shared solitude? During what past but still passing moment? And what melancholy and refreshing, transparent and perplexing, transient and undying music do we hear?

O listen! for the Vale profound

Is overflowing with the sound.

This double speaks lyrically and repetitively to himself of an anonymous singer who seems immortally lost in the field of Nature. But because he speaks for three stanzas in a repeatable present, his voice almost merges with that of the poem itself, which seems now to sing to us of an overflowing song whose mystery it shares. And as these "plaintive numbers flow," the voice of the poem recalls not only the Wordsworths' meeting with companies of reapers and Wilkinson's more solitary meeting, but also Bowles' lone bird at day's departing hour, Thomson's sad Philomel pouring forth her plaint, Collins' Maid compos'd, whose numbers steal through her darkening Vale, and the ballad-voice itself with its repeated harvest of loss.

The music in my heart I bore

Long after it was heard no more.

On the horizon of Nature a Maiden sings "As if her song could have no ending," but with her, in the shared poetic voice, sings Wordsworth's pensive muse.

III

If poetry recognizes that the voice itself constitutes its world, Nature can no longer seem the horizon. Then the voices in and of the poem can begin to converge. And then, in a self-distrusting poetry that often rebuts Wordsworth's, a beauteous evening can be etherized, a little old man not all alive nor dead can dream his own place of self-starved hope, and "Whispers of Immortality" can utter 
a landscape where daffodil bulbs stare from eye-sockets and we crawl "between dry ribs / To keep our metaphysics warm." The most intense voices in Eliot's poetry move toward a horizon neither external nor internal but quite literally beyond formulation. 4 There they meet a silent presence.

The solitary reaper of Eliot's early poetry stands in an unformulated field, her arms full of flowers. Not that she is much less concrete than the Highland Lass: neither girl is specified beyond thematic necessity. The difference is rather in the horizon toward which the naming voice moves, the implicit context which defines the encounter, the ground on which the figure appears.

Stand on the highest pavement of the stair-

Lean on a garden urn-

Weave, weave the sunlight in your hair-

This double also speaks in what seems a repeatable present, a moment of epitaph that passes into retrospection:

She turned away, but with the autumn weather

Compelled my imagination many days .... .

But the plaint in "La Figlia Che Piange" is silent-doubly so because hypothetical: "So I would have had her stand and grieve." The voice in this poem isn't recalling an encounter so much as constructing a gesture and a pose. What happened between him and the girl is beyond saying, but we can hear what he meets on the horizon of his present formulations: his guilty evasion of guilt.

\section{I should find}

Some way incomparably light and deft,

Some way we both should understand,

Simple and faithless as a smile and shake of the hand.

It is almost as if a Margaret, a Mariana, a Maud, a Blessed Damozel, were here addressed by a poet who suspects that he is capable of his own late romantic "Vaudracour and Julia."

Sometimes these cogitations still amaze

The troubled midnight and the noon's repose.

If the romantic reverence for the abandoned woman here shares a secret, that is only because the voice of the poem isn't displacing guilt or selfpity through art but is exploring its capacity for that maneuver. It therefore passes beyond the bad faith endemic in its heritage, and beyond the more tempting Laforguean music of self-irony, toward another kind of grace. The muse here invoked by a self-confessed Tereus must be a violated and mutely weaving Philomel. But in her silence an inviolable voice intimates the possibility of another name. The epigraph is not Wordsworth's question, "Will no one tell me what she 
sings?" but that of an exiled traveller and son who recognized a purpose greater than he could know: "O quam te memorem virgo . . . ." Aeneas' question leads along a difficult way, through repeated raids on the inarticulate, toward the pensive muse of the later poetry, a Lady of silences, torn and most whole.

We can always hear in the silence a word that calls us radically into question. That purgatorial mystery of movement toward the unformulated is denied but secretly met by Prufrock, Gerontion, and the Hollow Men. As these voices speak their own situations, they close themselves into the predicaments they define. Reflexive but afraid of the open, they answer the silent word only with veerings and ellipses, disarming questions and subtle denials. "And should I then presume? / And how should I begin?" "After such knowledge, what forgiveness?" "Not that final meeting . . ." Their speech itself is founded on possibilities they frustrate. "Let us go then, you and I . . " Like another Guido, Prufrock wants to say "you" without admitting the implications of the word. "I would meet you upon this honestly." Gerontion wants an honest meeting devoid of human content. ". . . We whisper together . .." The Hollow Men declare an intimate community of meaninglessness. Wanting to converse but effectively denying that we are a conversation, such self-deceptive voices generalize themselves into a "we" that reaches out to claim all Western culture.

Following that speech with a fidelity that has sometimes been mistaken for endorsement, the voices of the poems enact a more genuinely conversational and historical "we." Sharing the voice of the poem, we can hear in the differences between it and that of our double a silent invitation to unfold our double's ostensible meanings and to ask: If Prufrock risked becoming an absurd Lazarus, if he allowed himself to drown, might he speak with a human voice? If Gerontion were absolute for death, might he no longer swaddle the word with darkness? If the Hollow Men emptied themselves in the silence, might they hear how to complete their self-aborted predications? These questions are not rhetorical but real. Each poem discloses a "we" whose evasive finality is actual for the poetic voice only as an uncompleted meaning. In more complex ways The Waste Land allows us to hear, through voices that define their death-in-life without fully intending or understanding their own definitions, the call of a possibly real death and consequent life.

In Ash-Wednesday, however, a voice alert to the unfolding meanings of the silent word moves from self-blocked circularity toward the ever-deepening present of the poetic voice. This double speaks, dies into listening, and speaks again-as he converses with himself, a historical community, ladies of silence, and a "Word unheard" at the centre on the horizon.

Because I do not hope to turn again

Because I do not hope

Because I do not hope to turn

Answering Cavalcanti, Ezekiel, and other prophetic and liturgical voices, that opening turn also answers the turn of an anxiously improvisatory voice who could say "I dare to hope": 
How oft, in spirit, have I turned to thee,

O sylvan Wye! thou wanderer thro' the woods,

How often has my spirit turned to thee!

And as the more profoundly self-purging voice in Ash-Wednesday concludes the inconclusible, his responding petition to presences on the horizon almost reverses the ethical meaning of those earlier cries to the river and to "dear, dear Sister!"

Sister, mother

And spirit of the river, spirit of the sea

Suffer me not to be separated

And let my cry come unto Thee.

Here the voice of the poem is no longer at an inherent distance from the solitary double whose speech it names. Moving toward the same horizon, it prolongs a listening meditation through deeper repetitions or hears more fully its own intricate turnings. Both voices know, as Little Gidding will say, that "Every phrase and every sentence is an end and a beginning, / Every poem an epitaph," and that if we die with the dying, we are also "born with the dead: / See, they return, and bring us with them."

After such knowledge of guilt and grace, the violated, drowned and inviolable muse of Eliot's poetry can speak through a poem that, answering Seneca and Shakespeare, also makes a freshly companionable response to Wordsworth. The convergent voices in and of "Marina" do not ironically invert the Wordsworthian meanings of the invisible bird, the renovating spot of time, and the epitaph that manifests an absent presence. Those meanings are quietly transposed to another field.

What seas what shores what grey rocks and what islands

What water lapping the bow

And scent of pine and the woodthrush singing through the fog

What images return

O my daughter.

Suspended in a silence beyond that of Winander or the Hebridean seas, moving through an ever-deepening present of shared solitude toward a horizon beyond formulation, we hear a call to resign this speech for "that unspoken . . . ."

What seas what shores what granite islands towards my timbers And woodthrush calling through the fog

My daughter. 
A no less reflexive poetry, in which voices know that "the word is the making of the world" and that they must listen "as if to hear, / Hear hard, gets at an essential integrity," may yet deny a silent word of guilt and grace:

Tell X that speech is not dirty silence

Clarified. It is silence made still dirtier.

Though denying the "Word unheard," Stevens' later poetry admits a similar paradox:

We say ourselves in syllables that rise

From the floor, rising in speech we do not speak.

And it makes a journey toward a "being of sound" from whom we "collect." The most intense voices in Stevens' poetry move toward a horizon of verbal possibility that resists complete formulation but is often called "poetry." There they meet the call of authentic speech. 5

West":

The solitary reaper of this poetry sings in "The Idea of Order at Key

It was her voice that made

The sky acutest at its vanishing.

She measured to the hour its solitude.

She was the single artificer of the world

In which she sang. And when she sang, the sea,

Whatever self it had, became the self

That was her song, for she was the maker.

No one needs to tell us what she sings: her almost invisible world is strangely transparent.

Then we,

As we beheld her striding there alone,

Knew that there never was a world for her

Except the one she sang and, singing, made.

But this elegiac repetition does expand a question:

Whose spirit is this? We said, because we knew

It was the spirit that we sought. ... .

And "when the singing ended and we turned / Toward the town," that spirit"more even than her voice, and ours"-moved not merely in the heart but in a transforming landscape, as "glassy lights" arranged, deepened, and enchanted night. Why? "Oh! Blessed rage for order, pale Ramon . . . ." That semi-invocation names what this double meets in song, in landscape, and in the naming through 
which he knows them: no blessed mood, and not quite something evermore about to be, but "The maker's rage to order words of the sea" in ever "ghostlier demarcations, keener sounds"-a rage that moves toward a vanishing-point or portal on the horizon where making might be revealing, where poetry might be life. That desire for speech both creative and cognitive is also known by the voice of the poem, which must hear itself both in a solitary singer who makes a world from what is unknowable prior to song and in a conversational voice who reveals a social world of poetry. The poem itself makes a world of stepping or sailing or singing beyond the westernmost key-but it does so by answering Wordsworth, Tennyson, and Whitman, and by inviting us to say ourselves in a transparent fiction that arranges, deepens, and enchants our actual dark.

The paradox is irresolvable, but Stevens' poetry answers its call more rigorously when disclosing voices less addicted to the "romantic intoning, the declaimed clairvoyance" and wanting "not to console / Nor sanctify, but plainly to propound." Not that the poetry propounds. A reflexive double tries to speak faithfully of a reality that doesn't exist apart from his words. Aware of inhabiting a "nature that is created in what it says," aware that "Creation is not renewed by images / Of lone wanderers," he will searchingly actualize his horizon by speaking about doing so. He will constantly redefine the landscape, the weather, and what he may hear from Wordsworth of the "universal intercourse" or the "complete I Society of the spirit when it is / Alone." And he will be led, through desire for the "acutest end of speech," love of the real that can be known only in naming, or skeptical fidelity to the spirit that moves in poetry, toward statements of final belief in his own transparent fictions of transparence. At the same time the voice of the poem will follow every uncertainty, exaltation, presumption, or collapse. "Exponent by a form of speech, the speaker / Of a speech only a little of the tongue," it will name the reality that becomes actual in its double's attempt to name-and so enact a more authentic transparence.

Aware of these possibilities, the voice in "Asides on the Oboe" speaks toward the fictive end of reflexive movement: a man "responsive / As a mirror with a voice, the man of glass, / Who in a million diamonds sums us up." That presence, the central man of American romanticism now become M. Teste's selfelucidating homme de verre, ${ }^{6}$ must be "the transparence of the place in which / $\mathrm{He}$ is" and so the poetic sponsor of the actual:

The glass man, cold and numbered, dewily cries,

'Thou art not August unless I make thee so.'

Clandestine steps upon imagined stairs

Climb through the night, because his cuckoos call.

Again the earth appears unsubstantial, a fit home for that invisible thing, a voice, a mystery. But for the poetic voice this cold and antique pastoral is one of several asides that explore the ironically self-limiting range of a quirky instrument always reaching for finalities.

In "A Primitive Like an Orb" a more uncertain voice tries to name the essential poem heard in lesser poems and finds that his Wordsworthian groping evolves its own apparent telos, a giant of nothingness "at the centre on the hor- 
izon." But the voice in "The Auroras of Autumn" must face a transparence that embodies less the fiction of finality than the terrifying finality of fiction.

This is where the serpent lives, the bodiless.

His head is air. Beneath his tip at night

Eyes open and fix on us in every sky.

This double must converse with "tinted distances" and "frigid brilliances," a ceaselessly changing landscape that is constituted from the memories and uncertainties of an entire life in poetry. He moves through turnings and farewells as difficult as those in Ash-Wednesday, through "the enigma of the guilty dream" toward an absent presence known only through poetry-a mother-muse who "gives transparence." The oboe voice had told himself to say that "final belief must be in a fiction." This voice must make an equivalent but more desperate claim: "There is or may be a time of innocence / As pure principle."

It is like a thing of ether that exists

Almost as predicate. But it exists,

It exists, it is visible, it is, it is.

In that willed vision of transparence sounds a hope that forces itself to be fed, the authentic speech of a voice bewildered by a horizon where everything speaks only through his enabling act-because his cuckoos call. But at the same time the poetic voice, answering the serpent for whom "l'univers n'est qu'un défaut / Dans la pureté du Non-être," names the convolutions of will that move to this ether-laden moment. And that naming speaks with us a more authentic transparence than innocence.

As if in confirmation the voice in "An Ordinary Evening in New Haven" tells of one who, "wandering on the stair of glass" or "outsensing distances," met a still presence on the horizon: "Life fixed him . . . / With its attentive eyes" in "looks that caught him out of empty air." Those were not the eyes of a changing serpent but of an "hidalgo" who remained "permanent, abstract, / A hatching that stared and demanded an answering look." After such knowledge of the call to authenticity on the horizon of poetry, voices recognize more fully that the transparence of the solitary voice must be a mutual presence. "Speak to your pillow as if it was yourself," says one to his vision of an old philosopher half-asleep at the end of life's pilgrimage, who is heard speaking "without speech" as if on a threshold where the design of all his words is realized. "Be orator but with an accurate tongue"-

so that each of us

Beholds himself in you, and hears his voice

In yours, master and commiserable man ....

Among such poems of mutual presence, the muse who brings "vivid transparence" can sing her even-song, "The Final Soliloquy of the Interior Paramour." An invisible voice that is an intrinsic plural, both in and of the poem, 
utters a plaint subdued by acceptance, an acutely honest fiat that reconstitutes our insufficient world in the light of the searching possible: "Light the first light of evening ...." As we hear the muse's voice in the poet's, and ours in hers, a Voice to Light gives Being, a Portia marvels-"How high that highest candle lights the dark"-and we make a dwelling-place in the evening air of poetry, "In which being there together is enough."

For Wordsworth, Eliot, and Stevens the shared poetic voice wants to hear itself in a solitary voice that moves toward a limited horizon. But for each poet the solitary voice meets on the horizon a paradoxical call that leads toward a partial rediscovery of the inclusive mystery of conversation. And each finds that the long poem must now name the attempt of the voice to name its calling.

Milton could name the quest for vocation through a modified epic. The voice of Paradise Regained hears itself in a solitary meditator who, in order to tell of "deeds / Above Heroic, though in secret done," invokes again the Spirit who brooded on the vast abyss. That narrator then hears himself in the hero of the quest, the Son of God who, "Thought following thought, and step by step led on," enters a "pathless Desert," a "woody maze," to "converse / With solitude." ". . . to what intent / I learn not yet," the Son can say. "Who brought me hither / Will bring me hence, no other Guide I seek." As the Son moves through the ordeal of false calls to explicit awareness of his mission, the exploratory narrator discovers his own call-and the poem names that double progress. But such a linear form becomes inadequate when the voices in and of the poem approach each other more closely and converse with solitude in a yet more "trackless field." The poem must now move through radically self-transcending passages-to what intent the meditating double himself hasn't yet learned-and that endless meditation must also tend toward circularity. Can the epic become an extended invocation to the muse, or a self-elucidating maze, in which a voice attacked by the temptations of Narcissus tries to name a call that is actual only in the moment of naming? Of the major answers to that question, from The Prelude to The Cantos and The Anathemata, Wordsworth's requires the "dim uncertain ways" of intimate confession, Eliot's the inconclusive music of verbal passages, and Stevens' the ironic rhetoric of pedagogical notes.

“. . . and should the guide I chuse / Be nothing better than a wandering cloud, / I cannot miss my way." The Prelude begins in a repeated present, with a certainty that speaks through a confession of uncertainty. Because his way is now lost, the voice in the poem listens to his past. Thought follows thought, the road seems to lie plain before him, and he sets forth "heroic argument" almost "hidden from the reach of words": the life of a "chosen Son" with "holy powers / And faculties," who has been fostered by Nature, tempted by abstraction, and helped to stand again in Nature's presence a "sensitive, and a creative soul." If that were a genuinely linear narrative issuing in the present, this double would have named his calling, found his way, and the poem would be a reflexive Paradise Regained. But when most linear, his narrative is yielding to the present temptation not of Godwinian but of Wordsworthian doctrine. His freshest and most intense lan- 
guage occurs in fragmentary, groping, and echoing passages, as if his calling were actual only in the approach to certain past meetings that point to a not quite discovered way-perhaps to the mystery of naming itself, in which he participates when with imperfect memory but with "an obscure sense / Of possible sublimity" he moves toward the unknown. But what he only glimpses, the shared poetic voice more steadily enacts. Following no cloud but the significantly wandering path made by its double's enigmatic meetings, tortured expositions, and circling leaps, it answers Milton more ambiguously as it names the attempt to name.

From the dawning moment of unconscious dedication, for example, we leap to a "not lifeless" memory that provides most ambiguous evidence of imaginative power: a meeting with a ghastly moon-lit figure, almost the incarnation of solitude, who speaks in "uncomplaining voice" with a "strange half-absence" as if "Remembering the importance of his theme / But feeling it no longer." Again, from the dejection of having already crossed the Alps we climb-by way of a selftranscending tribute to a thwarting vapor met on the horizon of poetry, "lifting itself up / Before the eye and progress of my Song" to say that our home is "with infinitude and only there"-down to a now superseded apocalypse of natural forces. Or again, from the asserted renewal in Nature's presence we leap back to a moment of search for the lost Guide, with the "visionary dreariness" of naked Pool, Beacon, and Girl with garments vexed by the wind, and then forward to a confession that "the hiding-places of my power / Seem open; I approach, and then they close . . .." And from the climactic naming of conversation on the horizon of Nature-naked Moon, sea of mist, and that "breach / Through which the homeless voice of waters rose"-we descend to an abstract discourse on intellectual love. The voice in the poem now supposes himself found, able to build a work that may endure. But the poetic voice has already enshrined his strange halfabsence in its own magnificent epitaph.

"Through the first gate, / Into our first world, shall we follow / The deception of the thrush?" A dry birdcall, heard on a horizon beyond formulation, enters our shared solitude. As The Prelude reflexively subsumes and transforms the plot of Paradise Regained, so Four Quartets subsumes and transforms that of The Prelude. Because this double's way isn't adequately constituted in present speech, he allows echoes to guide him-not to a renovating spot of time but toward a timeless moment that points to a present end. Hearing a silent word for which no form of speech is adequate, and knowing that the Word in the desert is always attacked by voices of temptation, he refracts himself into meditative, conversational, lyric, and didactic voices that compose a path of groping and selftranscending passages. Because we have always "had the experience but missed the meaning," and because "approach to the meaning restores the experience / In a different form," he doesn't try to find himself in linear time. He tries to be still and still moving, with a more self-distrusting sense of possible sublimity, through a purgatorial naming of the unknown that is always now. And after his climactic naming of conversation on this horizon-a communication tongued with fire as he walks with his ghostly double in a dead patrol-he doesn't declare himself found, able to build an enduring work, or even able to "see the Children sport upon the shore, / And hear the mighty waters rolling evermore." He proposes further exploration of our first world, so that we may find 
The voice of the hidden waterfall

And the children in the apple-tree

Not known, because not looked for

But heard, half-heard, in the stillness

Between two waves of the sea.

For a double who knows that time is no healer, that speech must abandon itself, and that he utters his own epitaph, such exploration must be in silence. But for the shared poetic voice it must be in returning again and again to "where we started," hearing more deeply the inconclusive music of these fragmentary and contrapuntal passages, approaching the meaning of an echoing form that is itself a timeless moment, and so naming this attempt to name the "voice of this Calling."

Words, after speech, reach

Into the silence. Only by the form, the pattern,

Can words or music reach

The stillness ....

"Begin, ephebe, by perceiving the idea / Of this invention, this invented world ...."This double seems himself a guide who cannot miss his way, dictating notes toward the poetics of the world. But his paradoxes already start to name a "must," a puzzling call on the horizon of poetry. Phoebus was "a name for something that never could be named." There was and is

a project for the sun. The sun

Must bear no name, gold flourisher, but be

In the difficulty of what it is to be.

But what naming won't impose its flourishes on the nameless? Can we name its sunny principle and changing actuality? Behind his pedagogical rhetoric this double has no answers but increasingly urgent questions. And his search also subsumes and transforms the plot of The Prelude, incidentally renaming the Arab, dove, ocean, wren, "abysmal instruments" making "sounds like pips / Of the sweeping meanings that we add to them," and a luminous image "Serenely gazing at the violent abyss." Because his way isn't adequately constituted in present speech, this double propounds-allowing reflexive speech itself to be his guide. He tries neither to find himself in time nor to lose himself in the timeless but to name the necessity and the impossibility of naming. He must give major man "No names"-and yet "It is of him . . . to confect / The final elegance." As he wrestles with that dilemma, his speculations, parables, and doubts compose a broken path that gropes and echoes through sudden rightnesses.

His search presses the dilemma to its fictive end. Is there a poetic speech "only a little of the tongue?" Or must a Canon Aspirin always declaim of a sister whose feelings fight off the "barest phrase" in the "excitements of silence"? Surely it must be possible "to find, / Not to impose," to "find the real, / To be stripped of every fiction except one, / The fiction of an absolute-" And, like 
another M. Teste with his Portius, ${ }^{7}$ he tries to identify himself with his angel and soar past his irresolvable paradox: "I have not but I am and as I am, I am." Too true: the orator with an accurate ear falls back into wry authenticity, no lasting visage in a lasting bush but "Cinderella fulfilling herself beneath the roof." Unable to transcend his own major predicate, he recantingly joins the idiot minstrelsy of romantic birds that repetitively practice their preludes: perhaps the "merely going round is a final good." Only after that uncertain acceptance can he converse directly with his beloved, the transparent fiction in which he must find the world:

Fat girl, terrestrial, my summer, my night, How is it I find you in difference, see you there In a moving contour, a change not quite completed?

Admitting that he should name her flatly, check her evasions, he moves through evocation of her changes to an imagined moment that will subvert all the teaching of the Sorbonne, when

I call you by name, my green, my fluent mundo.

You will have stopped revolving except in crystal.

This solitary double, who can love only his muse, must try to name his calling by naming his evasions and hers. He is his own continuous fictive epitaph. But the shared poetic voice, stripped of every fiction except Notes Toward a Supreme Fiction, follows that attempt at "faithful speech" with yet more reflexive fidelity and a speech only a little of the tongue, so naming without names the difficulty of what it is to be-in poetry.

The Prelude, Four Quartets, and Notes Toward a Supreme Fiction name increasingly problematic attempts of the solitary voice to name its calling. These poems and the conversation of which they are a part may suggest that, as poetry moves from the field of Nature into fields explicitly constituted by the voice itself, an ambiguous Wordsworthian fable of the quest for vocation continues to unfold its meaning. A Traveller once, ranging the Plain of Sarum "without a track / To guide" him, was "by the solitude overcome," and he saw a "sacrificial Altar, fed / With living men." But the Traveller continued to roam "through that wide waste," and at other moments he was more "gently charm'd": "the Waste / Was chear'd with stillness and a pleasant sound."

\section{FOOTNOTES}

1 The climax of this very essay, "Tradition and the Individual Talent," is an attack on the phrase "emotion recollected in tranquillity." A year earlier, in 1918, Eliot had told the readers of The Egoist that Wordsworth was a poet of "assured though modest merit." By 1933, however, in The Use of Poetry and the Use of Criticism, his references to Wordsworth and to Romanticism were less deprecatory. And by 1955, in "Goethe as 
the Sage," he could say: "Wordsworth was surely a great poet, if the term has any meaning at all."

2 Letters of Wallace Stevens (New York, 1966), pp. 792, 677 (1953, 1950).

${ }^{3}$ Letter to Clarkson, 1806, quoted by R. H. Fogle, The Idea of Coleridge's Criticism (Berkeley, 1962), p. 26.

4 The philosophical gloss on this position in Eliot's early prose is a version of Bradley's idealism-"Without words, no objects" (Knowledge and Experience in the Philosophy of F. H. Bradley [New York, 1964], p. 132)-but a more adequate gloss might be closer to Aristotelian or Thomist realism, in which the potential becomes fully actual only when named.

5 Even such late poems as "Not Ideas about the Thing but the Thing Itself," "Of Mere Being," and "The Course of a Particular," though sometimes misread in terms of a naive realism, do not imply other than a horizon of verbal possibility. The "thing itself" is a named thing. "A poet's words are of things that do not exist without the words," said Stevens in "The Noble Rider and the Sound of Words." I have described his commitment to "authentic speech" more fully in another essay: "On Speaking Humanly," in The Philosopher-Critic, ed., Robert Scholes (Tulsa, 1970), pp. 67-88.

6 "L'Homme de Verre" is a section in "Extraits du Log-Book de M. Teste": "Si droite est ma vision, si pure ma sensation, si maladroitement complète ma connaissance, et si deliée, si nette ma représentation, et ma science si achevée que je me pénètre depuis l'extremité du monde jusqu'à ma parole silencieuse; et de l'informe chose qu'on désire se levant, le long de fibres connues et de centres ordonnés, je me suis, je me réponds, je me reflète et me répercute, je frémis à l'infini des miroirs-je suis de verre."

7 Another extract from the "Log-Book": "Je ne sais pas telle chose; je ne puis pas saisir telle chose, mais je sais Portius qui la possède. Je possède mon Portius, que je manoeuvre en tant qu'homme et qui contient ce que je ne sais pas." 